\title{
EVALUATION OF HEALTH HAZARDS AMONG CADMIUM-EXPOSED WORKERS
}

\author{
By \\ Attia D.I.*; El Mahdy N.M**. and Radwan N.M.** \\ From \\ *Industrial Medicine \& Occupational Diseases Dept., Cairo Univ. \\ **National Egypt. Center of Env. \& Toxicol. Research, NECTR, Cairo Univ.
}

\begin{abstract}
:
Introduction: Cadmium is a cumulative multisystem metallic toxin widely used in industry causing occupational exposure, while the main source of cadmium in the general population is diet and smoking.
\end{abstract}

Aim of the work: To demonstrate the hazardous effects of long-term occupational exposure to cadmium as a multisystem metallic toxin.

Subjects and methods: The study included 42 male workers exposed to cadmium from the electroplating sections of one factory, with a mean age of $(41.19 \pm 1.44)$ years and 30 control subjects with a mean age of $(48.33 \pm 1.85)$ years. The two groups were matched as regards age, sex and socioeconomic status. Individuals included in the present study had to respond to a questionnaire and were subjected to thorough clinical examination, assessment of liver and kidney functions, serum electrolytes, blood cadmium level - as an exposure biomarker - complete urine analysis, ventilatory functions and prostate specific antigen as an early predictor of prostatic cancer.

Results: The prevalence of clinical manifestations was significantly higher among the exposed versus the control group. The blood cadmium and the PSA levels were found to be higher among the exposed group. Ventilatory functions showed statistically significant difference between both groups indicating an obstructive pattern due to inhalation of cadmium fumes. Also, there was a statistically significant difference between both groups regarding levels of blood urea, serum creatinine and some serum electrolytes. Urine analysis showed higher protein excretion in the exposed group.

Conclusion: Chronic occupational cadmium exposure in egyptian workers causes damage to different body systems and results in their dysfunction. Prostate specific antigen (PSA) can be used for screening of prostate cancer among cadmium-exposed workers.

Key words: Cadmium- Prostatic cancer- PSA- Renal toxicity- Ventilatory functionsCarcinogenicity. 


\section{Introduction:}

Cadmium (Cd) is a well-known hazardous heavy metal which is present in the workplace and in the living environments. It is generated as a by product of the mining of other metals e.g. lead, copper and zinc. It was presented by the Agency for Toxic Substances and Disease Registry as the 7th most toxic agent in the priority list of the top 50 hazardous substances (ATSDR, 2003).

Environmental and occupational exposure to cadmium is implicated in a number of clinical complications, primarily renal dysfunction and bone disease. Even at very low levels of exposure, this heavy metal can cause kidney damage (Järup, 2002 and Satarug and Moore, 2004). Also, Cd effects on reproductive outcomes have begun to emerge and recent studies have illustrated that the testis is exceedingly sensitive to $\mathrm{Cd}$ toxicity (Attia et al., 2006 ; Kusakabe et al., 2008 and Siu et al., 2009).

According to Herak-Kramberger and Sabolic in 2001, nephrotoxic heavy metals directly damage the integrity of proximal tubular cell plasma membrane thus causing shortening and loss of microvilli.

Chronic exposure to $\mathrm{Cd}$ can also lead to manifest disorders in the calcium metabolism, respiratory system and causes liver toxicity (Liu et al., 1992). Manca et al., in 1991, added to these findings, the risk of cardiomyopathy resulting from the accumulation of the metal in vital organs.

$\mathrm{Cd}$ acts as a hepatotoxin, producing hepatic dysfunction, which is characterized by increased excretion of the plasma alanine aminotransferase (GPT). It can cause various histopathological lesions in the liver, such as periportal liver cell necrosis and bile duct hyperplasia in rats (Mitsumori et al., 1998), cell death and regeneration (Tanimoto et al., 1993), dilatation of sinusoids as well as Kupffer cell enlargement (Sudo et al., 1996).

Cadmium- induced genotoxicity increases the risk of several cancers (Patrik, 2003).

Old studies revealed that Cadmium exposure has been associated with 3 types of cancer: prostate, kidney and bronchial. The predominance of prostate cancer was significant, but the incidence of other cancers was close to the expected figures (Kipling and Waterhouse., 1967 and Lemen et al., 1976).

The International Agency for Research on Cancer (IARC) had classified Cadmium as human Carcinogen (IARC, 1993 and Waalkes et al., 1999). Also, Zeng et al., in 2003 proved that cadmium causes testicular 
necrosis and is carcinogenic to the prostate; and Ewis et al., in 2006 confirmed the occurrence of carcinogenicity through apoptosis and cellular dysfunction. The study done by Sorahan and Esmen in 2004 that investigate the incidence of mortality from lung cancer in nickel-cadmium battery workers in relation to cumulative exposure to cadmium hydroxide did not indicate that cadmium hydroxide is an occupational lung carcinogen.

\section{Aim of the work:}

To demonstrate the hazardous health effects of occupational exposure to cadmium as a multisystem metallic toxin and to investigate the role of PSA in early detection of prostatic cancer.

\section{Subjects and Methods:}

The present work was carried out in an electroplating industry in Cairo. A written consent was taken from the studied group to perform the work.

The process of electroplating is the deposition of metallic layers on to conducting surfaces by making the cathode in an electrolytic cell with a suitable electrolyte which consists of a solution of a suitable salt (cadmium oxide or cadmium carbonate) of the metal being plated (Gaber and Yassin, 1994). Cadmium volatilizes readily during smelting and then condenses to form fine airborne particles that react almost immediately with oxygen to form respirable cadmium oxide fume. Potential worker exposure occurs from ore smelting operations, the mist above cadmium-containing electroplating baths. Also, exposure occurs during cutting, soldering and welding cadmium-plated steel.

The exposed group included 42 workers and the control group included 30 workers chosen from the administrative zone, far from any exposure. All members of the examined groups were males.

Individuals included in the study were interviewed to complete a standardized questionnaire including medical history about genitourinary, renal and respiratory symptoms; in addition to personal, present, past, family and occupational histories with special emphasis on the nature of the work, type of exposure, duration of work and the use of protective equipment.

General examination was carried out and local examination of the chest, heart and abdomen.

\section{Laboratory analysis:}

Ten c.c. of venous blood were taken from the exposed workers and the controls under complete aseptic condition for measurement of hemoglobin level, total and differential leucocytic count, total red 
blood cell count and platelet count; chemical analysis and PSA measurement.

Chemical analysis was performed using the photometer PM 750 for measurement of SGPT (ALT), SGOT (AST) (normal values up to $45 \mathrm{IU}$ and $36 \mathrm{IU}$ respectively). Serum creatinine (normal value $=0.5-1.2 \mathrm{mg} \%$ ), blood urea (normal value $=19-50 \mathrm{mg} \%$ ). Serum electrolytes were measured using the AVL apparatus. Normal values for serum sodium $=136-145 \mathrm{mM} / \mathrm{L} ;$ Potassium $=$ 3.5-5 mM/L and Calcium $=8.8-12 \mathrm{mg} / \mathrm{dl}$ ).

Total PSA was measured using an Elisa (Enzyme - linked Immunasorbent Assay) for quantitative analysis, normal level $=$ $2.4 \mathrm{ng} / \mathrm{ml}$.

Cadmium was determined in blood samples using Atomic Absorption Spectrophotometer (AAS) PYE Unicam SP9. The concentration of cadmium in blood was expressed as $\mu \mathrm{g} / \mathrm{L}$ (normal value up to $1 \mu \mathrm{g}$ /L) (Hairrison and Laxen, 1981).

A sample of urine was collected from the studied group in a sterile container for urine analysis.

Environmental monitoring was done by collecting air samples from the general working environment inside the electroplating chamber from different department of the factory, continuously during work time ( 8 hours/day). The filtration method was used for collecting the suspended particulate matters (Perry and Young, 1977). The air was drawn through a membrane filter, vaccum pump and calibrated gas meter. Then the membrane filter was digested in nitric acid and perchloric acid and cadmium concentration was then determined in the dust using atomic absorption spectrophotometer. For comparison, samples were also drawn from outside the electroplating chamber.

Resting ventilatory function tests were performed using the Medgraphic spirometer in the Fitness and Rehabilitation Unit, Kasr El Aini Hospital. The following parameters were measured for each subject: FVC, FEV1, FEV1/FVC\%, FEF 25\%, FEF $50 \%$, FEF $75 \%$, FEF $25-75 \%$, MVV, SVC, IC and ERV. The values were assessed from the flow volume curve using the standard technique according to the American Thoracic Society recommendations (ATS, 1995). It is advocated that lung function tests are considered abnormal only when the value deviates by $20 \%$ or more from the mean normal value (100\%) (Ruppel, 2003). Results were expressed as $\%$ of predicted.

\section{Data handling and Statistical Analysis:}

Data were collected, checked, revised and entered the computer. Data were analyzed by SPSS statistical package version 
15. Excel computer program was used to tabulate the results, and represent them graphically. Qualitative variables were expressed as percentages.

The differences in the distribution of the qualitative variables were tested by the Chi square non-parametric test at a level of significance $\mathrm{p}<0.05$.

Quantitative variables from normal distribution were expressed as mean and standard error (S.E.) The difference between, before and after was tested by using Paired $\mathrm{t}$-test at a level of significance $\mathrm{p}<0.001$.

The difference between groups were tested by using independent t-test at a level of significance $\mathrm{p}<0.05$.

Pearson correlation coefficient was calculated to measure the power and direction of the relationship between the quantitative variables at $\mathrm{p}<0.05$ (Armitage, 1971).

\section{Results:}

The work was conducted on 42 male workers exposed to cadmium during electroplating and 30 males as a control group. Both studied groups were statistically matched as regards age, sex and socioeconomic status.

The age of the exposed group ranged from 28 to 54 years with a mean value of $(41.19+1.44)$, while the age of the control group ranged from 30 to 58 years with a mean value of $(48.33+1.85)$ with no statistically significant difference between both groups (p-value 0.06).

Thirty two subjects among the cadmium- exposed group (76.2\%) were cigarette smokers versus 10 subjects $(33.3 \%)$ of the control group and none were ex-smokers. Sixteen subjects $(38.1 \%)$ of the exposed group had a duration of employment less than 15 years with a mean value of $(12.25$ $+0.53)$ while 26 subjects $(61.9 \%)$ had been employed for more than 15 years with mean value of $(19.38+0.82)$.

As regards different clinical manifestations, table (1) shows a statistically significant difference between exposed workers and the control group as regards respiratory symptoms in the form of cough, expectoration, dyspnea and asthma or asthmatic like attacks; renal symptoms in the form of recurrent renal colic, frequency and dysuria; and prostatic symptoms in the form of urgency, retention and sexual problems.

Cd and PSA level in table (2) shows significantly higher blood cadmium levels and prostatic specific antigen (PSA) in exposed workers when compared to the controls (p.value < 0.05). As regard the duration of exposure, blood cadmium level among 
exposed workers employed for more than 15 years was higher although the difference was not statistically significant. Also higher PSA levels were recorded among exposed group employed for more than 15 years.

The effect of smoking on PSA level was not significant but there was a nonsignificant higher blood cadmium level among smokers compared to non-smokers (p-value 0.770).

Table (3) illustrates the correlation between PSA and different parameters; it shows positive correlation of PSA with age and duration of exposure.

Table (4) shows that SGPT and SGOT levels were higher in the exposed than the controls but the difference was not statistically significant. In addition, blood urea level is significantly higher in the workers than in the controls, serum creatinine is also higher but the difference was not statistically significant between both groups. The table also shows significantly higher level of sodium in exposed workers when compared to the controls. Also serum calcium was found to be significantly lower in the exposed workers than in the controls.

Table (5) shows the results of urine analysis of the studied groups, there is a statistically significant difference between exposed workers and control group in urinary protein excretion and urinary crystals (oxalate, urates and phosphates).

As regards pulmonary function parameters, (table 6) shows a statistically significant difference between exposed workers and controls as regards FVC, FEV1, FEV1/ FVC, FEF 50 and MVV percentage of predicted.

Environmental monitoring was done by collecting air samples from the general working environment inside the electroplating chamber from different department of the factory, continuously during work time ( 8 hours/day). Results revealed different concentrations with maximum level $=$ $10 \mu \mathrm{g} / \mathrm{m} \square$ minimum level $=0.91 \mu \mathrm{g} / \mathrm{m \square}$ Mean + S.D $(6 \mu \mathrm{g} / \mathrm{m} \square+1.8)$. The maximum value obtained was 10 times greater than the $1 \mu \mathrm{g} / \mathrm{m} \square$ set by OSHA (1990). 
Table (1): Comparison between exposed workers and control group as regards symptoms.

\begin{tabular}{|c|c|c|c|c|c|c|}
\hline \multirow{2}{*}{} & \multicolumn{2}{|c|}{$\begin{array}{c}\text { Exposed workers with } \\
\text { symptoms }\end{array}$} & \multicolumn{2}{c|}{$\begin{array}{c}\text { Control with } \\
\text { symptoms }\end{array}$} & \multirow{2}{*}{$\boldsymbol{\chi 2}$} & p-value \\
\cline { 2 - 7 } & no & $\%$ & no & $\%$ & \\
\hline \multirow{2}{*}{ Respiratory } & 24 & $57.1 \%$ & 6 & $20.0 \%$ & 5.40 & $0.020 *$ \\
\hline \multirow{2}{*}{ Renal } & 18 & $42.9 \%$ & 4 & $13.3 \%$ & 4.46 & $0.041^{*}$ \\
\hline Prostatic & 22 & $52.4 \%$ & 4 & $13.3 \%$ & 6.23 & $0.013 *$ \\
\hline
\end{tabular}

* significant

Table (2): Comparison between exposed workers and control group as regards the blood cadmium and prostate specific antigen levels.

\begin{tabular}{|c|c|c|c|c|c|c|c|c|}
\hline & \multirow{2}{*}{ Min. } & \multirow{2}{*}{ Max. } & $\begin{array}{c}\text { Exposed } \\
\text { workers }\end{array}$ & \multirow{2}{*}{ Min. } & Max. & Control & \multirow{2}{*}{ t-value } & p-value \\
& & & Mean \pm S.E & & & Mean + S.E & & \\
\hline $\begin{array}{c}\text { Cd in } \\
\text { blood } \\
(\mu \mathrm{g} / \mathrm{L})\end{array}$ & 0.8 & 1.6 & $1.21 \pm 0.05$ & 0 & 0.8 & $0.22 \pm 0.08$ & 10.97 & $0.000^{* *}$ \\
\hline $\begin{array}{c}\text { PSA } \\
(\mathrm{ng} / \mathrm{ml})\end{array}$ & 1.9 & 3 & $2.64 \pm 0.06$ & 1.2 & 1.8 & $1.53 \pm 0.05$ & 13.81 & $0.000^{* *}$ \\
\hline
\end{tabular}

** Correlation is highly significant at the 0.001 level 
Table (3): Correlation between PSA and different parameters

\begin{tabular}{|c|c|c|}
\hline Age & $\begin{array}{c}\text { Pearson } \\
\text { Correlation r }\end{array}$ & p-value \\
\hline Cadmium & $0.7 * *$ & 0.001 \\
\hline Duration of exposure & 0.14 & 0.09 \\
\hline
\end{tabular}

** Correlation is highly significant at the 0.001 level.

* Correlation is significant at the 0.05 level.

Table (4): Comparison between exposed workers and control group as regards liver function studies, kidney function studies and serum electrolytes.

\begin{tabular}{|c|c|c|c|c|}
\hline & Exposed workers & Control & \multirow{2}{*}{ t-value } & p-value \\
\cline { 2 - 3 } & Mean \pm S.E & Mean \pm S.E & 0.46 & 0.646 \\
\hline SGPT(IU) & $19.67 \pm 4.75$ & $17.57 \pm 1.79$ & 0.70 & 0.490 \\
\hline $\begin{array}{c}\text { SGOT(IU) } \\
\text { Urea (mg\%) }\end{array}$ & $17.80 \pm 2.88$ & $15.71 \pm 1.47$ & 2.79 & $0.043^{*}$ \\
\hline $\begin{array}{c}\text { Creatinine } \\
(\mathrm{mg} \%)\end{array}$ & $1.01 \pm 0.08$ & $0.95 \pm 0.05$ & 0.52 & 0.610 \\
\hline $\begin{array}{c}\text { Sodium } \\
(\mathrm{mM} / \mathrm{L})\end{array}$ & $142.48 \pm 0.69$ & $139.40 \pm 0.58$ & 3.24 & $0.003^{*}$ \\
\hline $\begin{array}{c}\text { Potassium } \\
(\mathrm{mM} / \mathrm{L})\end{array}$ & $3.99 \pm 0.10$ & $4.05 \pm 0.08$ & 0.45 & 0.657 \\
\hline \begin{tabular}{c} 
Calcium (mg/dl) \\
\hline
\end{tabular} & $8.81 \pm 0.13$ & $9.05 \pm 0.12$ & 1.26 & 0.216 \\
\hline
\end{tabular}

* There is a significant difference between patient and control group by using independent t-test at $\mathrm{p}<0.05$ 
Table (5): Comparison between urine analysis of exposed workers and control group.

\begin{tabular}{|c|c|c|c|c|c|c|}
\hline & \multicolumn{2}{|c|}{ Exposed workers } & \multicolumn{2}{|c|}{ Control } & \multirow{2}{*}{ t-value } & \multirow{2}{*}{ p-value } \\
\hline & no & $\%$ & no & $\%$ & & \\
\hline Proteins & 20 & $16.9 \%$ & 4 & $12.5 \%$ & 4.63 & $0.03 *$ \\
\hline Glucose & 14 & $11.9 \%$ & 12 & $37.5 \%$ & 0.08 & 0.780 \\
\hline Oxalate & 26 & $22.0 \%$ & 8 & $25.0 \%$ & 4.77 & $0.029 *$ \\
\hline Urates & 36 & $30.5 \%$ & 4 & $12.5 \%$ & 12.80 & $0.000 * *$ \\
\hline Phosphates & 22 & $18.6 \%$ & 4 & $12.5 \%$ & 6.23 & $0.013 *$ \\
\hline
\end{tabular}

* Significant difference by using Chi square test at $\mathrm{p}$-value $<0.05$.

** High significance at the 0.001 level.

Table (6): Ventilatory functions expressed as \% of predicted in both exposed and control groups

\begin{tabular}{|c|c|c|c|c|}
\hline & Exposed workers & Control & \multirow{2}{*}{ t-value } & \multirow{2}{*}{ p-value } \\
\cline { 2 - 3 } & Mean \pm S.E & Mean \pm S.E & & $0.002^{*}$ \\
\hline FVC \% of pred. & $95.13 \pm 1.38$ & $101.43 \pm 1.22$ & 3.39 & $0.046^{*}$ \\
\hline FEV1 \% of pred. & $93.00 \pm 1.32$ & $96.95 \pm 1.31$ & 2.07 & $0.019 *$ \\
\hline FEV1/FVC \% & $79.48 \pm 1.16$ & $83.33 \pm 0.88$ & 2.46 & 0.612 \\
\hline FEF25\% of pred. & $86.90 \pm 1.93$ & $88.13 \pm 0.83$ & 0.51 & $0.000 * *$ \\
\hline FEF50\% of pred. & $63.90 \pm 2.90$ & $83.47 \pm 1.02$ & 5.51 & 0.377 \\
\hline FEF75\% of pred. & $79.57 \pm 6.09$ & $86.07 \pm 0.73$ & 0.89 & 0.192 \\
\hline FEF25-75\% of pred. & $82.33 \pm 3.97$ & $88.80 \pm 1.42$ & 1.33 & $0.000 * *$ \\
\hline MVV \% of pred. & $73.62 \pm 3.20$ & $90.07 \pm 0.98$ & 4.22 & 0.644 \\
\hline SVC \% of pred. & $99.52 \pm 2.37$ & $98.07 \pm 1.63$ & 0.47 & 0.288 \\
\hline IC \% of pred. & $107.33 \pm 3.21$ & $102.53 \pm 2.72$ & 1.08 & 0.580 \\
\hline ERV \% of pred. & $83.62 \pm 6.39$ & $87.93 \pm 1.73$ & 0.56 & 0.13 \\
\hline
\end{tabular}

* Significant difference by using Chi square test at $\mathrm{p}$-value $<0.05$.

** High significance at the 0.001 level. 


\section{Discussion:}

The increasing pollution by cadmium and its influence on human health has attracted great interest during this decade. Cadmium $(\mathrm{Cd})$ is an environmental toxicant and an endocrine disruptor in humans and rodents. Several organs (e.g. kidney, liver) are affected by $\mathrm{Cd}$ (Siu et al., 2009). It has been shown in studies on industrial workers as well as general population that excessive exposure to cadmium can cause renal tubular dysfunction (Jarup et al., 1993).

The Cd-binding protein metallothionein (MT) plays important roles in Cd retention in tissues and dramatically decreases biliary excretion of $\mathrm{Cd}$. Cd bound to MT is responsible for $\mathrm{Cd}$ accumulation in tissues and the long biological half-life of $\mathrm{Cd}$ in the body. Induction of MT protects against acute toxicity to the liver and lung. Intracellular MT also plays important roles in ameliorating $\mathrm{Cd}$ toxicity following prolonged exposures, particularly chronic $\mathrm{Cd}$-induced nephrotoxicity, osteotoxicity, and toxicity to the lung, liver and immune system. Thus, MT is critical for protecting human health from Cd toxicity (Klaassen et al., 2009).

These data explain our results where the kidney function tests revealed that the blood urea and serum creatinine levels of exposed workers were higher than normal with a statistically significant difference in the urea level among exposed workers when compared to the control group which could be an indication of early induction of nephrotoxicity (table 4).

In accordance with our results, Chia et al., in 1992 demonstrated high level of urea and creatinine among $\mathrm{Cd}$ exposed workers even with $\mathrm{Cd}$ level below the critical concentration. Prasad and Nath, in 1995 and Aoshima et al., in 1995 reported significantly higher values of serum creatinine among exposed groups. Bar-Sela et al., in 1992 found that workers who had worked for more than 10 years had more urinary tract problems including high level of urea and creatinine.

The initial cadmium-induced renal dysfunction is manifested as tubular proteinuria (Järup, 2002). Unfortunately, cadmiuminduced tubular proteinuria is irreversible, and continued exposure to cadmium may lead to glomerular damage with decreased glomerular filtration rates. Severe cadmium-induced nephrotoxicity may manifest as renal glucosuria, aminoaciduria, hyperphosphaturia, hypercalcuria, polyuria, renal stones and decreased ability to buffer acid load (Kazantzis, 2004).

Changes in urinary urates and phosphate tend to be significant only after other 
markers of renal damage are clearly elevated (Mason et al., 1988). These data typically explain our results where the elevation of blood urea and serum creatinine were associated with proteinuria, phosphaturia and changes in urinary urates and other crystals (table 5). The present results were in accordance with the results of Sato et al., in 1995 which demonstrated frank proteinuria and disturbed kidney functions in the form of elevation of blood urea and serum creatinine. Also, Tanimoto et al., in 1993 reported that frank proteinuria was preceded by excretion of low molecular weight protein such as $\beta 2$ microglobulin and aminoaciduria, glucosuria, phosphaturia and calcium wasting.

Our results are also consistent with those obtained by Shaikh et al., in 1987 whose results confirmed not only that occupational exposure to cadmium over long periods resulted in renal dysfunction but also the levels of all urinary parameters increased with the duration of employment.

In individuals living in a cadmium-polluted areas, Sangster et al., in 1984 found that cadmium excretion, protein excretion and glucose excretion were significantly higher than in corresponding controls.

High incidence of multiple stone formation have been observed among work- ers exposed to cadmium. Stone formation is likely to be secondary to disruption of calcium metabolism due to kidney damage (Jarup and Elinder, 1993 ) which supports our results in which calcium was found to be lower in cadmium-exposed workers compared to controls although the difference was not statistically significant. Moreover, Yang et al., in 2009 stated that as cadmium stimulates calcium release from the endoplasmic reticulum, it induced elevation of calcium which depolarizes the mitochondrial membrane potential and then leads to apoptosis leading to nephrotoxicity.

In the present study the level of blood cadmium of exposed workers who had uncontrolled exposure to $\mathrm{Cd}$ fumes for more than 5 years; was found to be higher than in control group (table 2). Simth et al., in 1986; Aayad et al., in 1988 and Iwata et al., in 1991 had also demonstrated in their studies increased Cd concentration among exposed workers. In addition to this, the level was found to be higher with increased duration of exposure; which was also reported by Kawada et al., in 1990.

Cadmium and cadmium compounds are known to be human carcinogens (Robert et al.,2004). Cadmium causes various genitourinary disorders and is a carcinogen for the prostate ( Jan_Dar et al.,2009 ). An association between human and rodent $\mathrm{Cd}$ 
exposure and prostate cancers was found, especially in the portions where MT is poorly expressed (Klaassen et al., 2009).

In general, increased proliferative activity in cells resulting from toxicity, cell death and regeneration due to toxicants, has been reported to be closely associated with tumor development. The persistent enhancement of cell proliferation as a result of damage caused by toxicants might be crucial for carcinogenesis. This appears to be the mechanism of action of non-genotoxic carcinogenesis (Yoshida et al.,1999).

Prostate specific antigen (PSA) is a protein produced by cells of the prostate gland, There can be different reasons for an elevated PSA level, including prostate cancer, benign prostate enlargement, inflammation, infection, age, and race. In general, however, the higher a man's PSA level, the more likely cancer is present.

Edwin et al., in 2008 found that PSA levels were $22 \%$ higher among american men who had cadmium levels above median.

Robert et al., in 2004 stated that the probability of surviving prostate cancer in the United States is about $95 \%$ as early diagnosis by routine examination and testing of older men for PSA has enhanced survival.
In the past, a PSA level below $4.0 \mathrm{ng} /$ $\mathrm{ml}$ was considered as normal. However, in one large study prostate cancer was diagnosed in 15.2 percent of men with a PSA level at or below $4.0 \mathrm{ng} / \mathrm{ml}$ (Thompson et al., 2004). In another study, 25 to 35 percent of men who had a PSA level between 4.1 and $9.9 \mathrm{ng} / \mathrm{ml}$ and who underwent a prostate biopsy were found to have prostate cancer, meaning that 65 to 75 percent of the remaining men did not have prostate cancer despite higher PSA level (Smith et al., 1997).

In the current study, the mean PSA level, although within normal range, was found to be significantly higher in exposed workers when compared to the controls (table 2). This could be attributed not only to advancement of age of the workers, but to cadmium exposure as well. PSA levels showed negative correlation with cadmium level, and positive correlation with age and with the duration of exposure (table 3 ) which means that PSA level continues to rise over time, a finding that should be put into consideration in periodic examination of workers with performance of digital rectal examination (DRE). If no symptoms to suggest cancer are present, we should recommend repetition of PSA tests regularly to watch for any changes. If a man's PSA level has been increasing or if a suspicious 
lump is detected during a DRE, we may recommend biopsy procedure or other tests to determine if there is cancer or another problem in the prostate.

As regards liver function studies, our results showed no significant difference between exposed workers and control group as regard SGPT and SGOT levels (table 2) which was consistent with the results of Kamiyema et al., in 1995 which revealed normal levels within the studied groups. In contrast Novelli et al., in 1998 and ElMaraghy et al., in 2001 found significant elevation of SGPT and SGOT after experimental administration of $\mathrm{Cd}$ chloride to rats. Manca et al., in 1991 found minimal hepatotoxicity among examined workers.

Respiratory symptoms were common among industrial workers exposed to high cadmium concentration (Magnus, 1981) which is consistent with our results that showed statistically significant difference between the exposed workers and the control group in the form of chronic cough, expectoration, dyspnea and repeated asthmatic attacks in $80 \%$ of the exposed workers (table 1). Repeated or prolonged inhalation of cadmium dust or fumes have been reported to produce an obstructive pulmonary syndrome and possibly emphysema with abnormal lung functions (Emara and Abdel Samie, 1991).
Cadmium fumes are not dissolved in the upper respiratory tract but penetrate into alveoli. This accounts for high incidence of pulmonary disease among $\mathrm{Cd}$ exposed workers and produces severe pulmonary damage that may lead later to fibrosis or emphysema (Frankel et al., 1991).

A new study has also confirmed that $\mathrm{Cd}$ induces centrilobular emphysema and chronic obstructive pulmonary disease (COPD) (Fievez et al., 2009) which is consistent with our results. Also, pulmonary inflammation induced by cadmium inhalation could be associated with oxidative stress (Kischvin et al., 2006).

A potential mechanism for $\mathrm{Cd}$-induced emphysema was studied recently by Zhao et al., in 2009. They found that the levels of the lung metal scavenging thiols, e.g., metallothionein (MT) and glutathione (GSH), were both upregulated upon longterm $\mathrm{Cd}$ exposure. This $\mathrm{Cd}$ upregulation of cellular thiols may be a critical cellular event facilitating downregulation of lysyl oxidase (LO), a copper-dependent enzyme for crosslinking collagen and elastin in the extracellular matrix (ECM), causing suppression of synthesis of collagen, a major structure component of the lung ECM. As a result, emphysematous lesions were generated. 
There has been a number of experimental studies which demonstrated that $\mathrm{Cd}$ inhibits the pulmonary defense mechanisms against infection. Also, it has been proved that there is genetic susceptibility to emphysema as subjects with $\alpha 1$-antitrypsin deficiency are less able to protect themselves from injury from proteases generated from inflammatory insults to the lung. It was observed that inhibition of $\alpha 1$ antitrypsin by $\mathrm{Cd}$ may therefore play a role in the pathogenesis of Cd- induced emphysema (Emara and Abdel Samie, 1991 and Hendrick, D. 2004).

Sakurai et al., in 1982 and Jakubowski et al., in 2004 reported that exposure to high cadmium concentrations in the workplace resulted in the significant deterioration of some lung functions expressed as $\%$ of predicted (FVC, FEV1, FEV1/ FVC\%, $\mathrm{PEF}$, maximum midexpiratory flow (MEF) at $25 \%, 50 \%$, and $75 \%$ ) and respiratory impedance in the workers, suggesting airway obstruction . In agreement with these studies, the results of the present study demonstrated statistically significant reduction in the ventilatory functions, expressed as \% of predicted, (FVC, FEV1, FEV1/ FVC\%, $\mathrm{MVV}$, forced expiratory flow (FEF50\%) of the exposed workers when compared to the controls (Table 6).
Our results were also consistent with those obtained by Boudreau et al. 1989 who reported that cadmium inhalation affected the pulmonary functions.

However, Edling et al., in 1986 found that there was no significant difference in lung function data (FVC, FEV1, FEV1/ $\mathrm{FVC} \%$ and MMF) between the cadmiumexposed and reference groups and there was no dose-response relation within the exposed group.

The study of Pocock et al., in 1988 revealed that cigarette smoking was associated with higher cadmium body burden as they found that $95 \%$ of men who never smoked had cadmium blood concentration less than $1 \mu \mathrm{g} / \mathrm{L}$, while $80 \%$ of men who smoked more than 20 cigarettes per day had values higher than $1 \mu \mathrm{g} / \mathrm{L}$.

The blood and urinary cadmium reflect the total cadmium body load which has 2 main sources; First due to occupational exposure (concentration of cadmium in atmospheric air $\square$ duration of exposure); second due to the load of cadmium in cigarettes; which provides an additional load of $\mathrm{Cd}$ among smokers. The mean value of $\mathrm{Cd}$ among smokers was higher than the level in non smokers (Bajpai et al., 1994).

However, in our results, the difference in blood $\mathrm{Cd}$ level between smokers and non- 
smokers was not statistically significant because we measured the blood $\mathrm{Cd}$ level which reflects the recent exposure rather than body burden (Roles et al., 1989); while urinary $\mathrm{Cd}$ level reflects the total $\mathrm{Cd}$ body burden. The same results were reported by Fahim et al., 1990. According to Willers et al., in 1988 direct measurement of cadmium levels in body tissues confirms that smoking roughly doubles cadmium body burden in comparison to non-smoking.

Finally, recent studies suggest that taking care of the nutrition of cadmium exposed workers may play a role in their protection against its toxicity e.g. onion and garlic may exert their protective effects via reduction in lipid peroxidation and enhanced antioxidant defense (Suru, 2008). Also, Zinc and antioxidants intake may offer protection against cadmium induced health hazards (Edwin et al., 2008 and Renugad, 2009). The effect of supplemental magnesium ( $\mathrm{Mg}$ ) has been studied on the kidney levels of cadmium, zinc, and copper of mice exposed to toxic levels of cadmium. Results showed that in acute $\mathrm{Cd}$ intoxication, $\mathrm{Mg}$ pretreatment resulted in significant decrease of $\mathrm{Cd}$ in the kidney after 4 and $6 \mathrm{~h}$, compared with animals given only $\mathrm{Cd}$. Under the condition of subacute $\mathrm{Cd}$ intoxication, $\mathrm{Mg}$ supplementation reduced Cd kidney content after 2 weeks for about $30 \%$, compared with animals treated with Cd only (Danijela et al., 2006). This study also raises the importance of the possible use of magnesium as a supplement in exposed workers; a finding that should be well investigated in future researches.

\section{Conclusion \& Recommendations:}

Cadmium is a multi system toxicant and its compounds are known to be human carcinogens based on findings of increased risk of prostatic cancer among exposed workers. Prostate Specific Antigen (PSA) can be used for diagnosis and early detection of cancer of the prostate. However, further studies and investigations are needed to clarify our understanding of the effects of cadmium on different body systems.

Although there are many parameters suggested for use as potential biological indicators for cadmium toxicity, none appears to be suitable by itself. Based on this fact and on the different studies, the measurement of urinary cadmium, metallothionein, and $\beta 2$-microglobulin appear to be the most rational strategy to use in detecting and monitoring cadmium toxicity. Also, there has been an interest in monitoring $\alpha$ 1- antitrypsin level in plasma.

Strict supervision and application of preventive measures in the work environment with periodic medical follow-up of exposed workers are of great importance. 
Proper nutrition of $\mathrm{Cd}$ exposed workers may play a role in their protection against its toxicity e.g. onion and garlic. Also, Zinc and antioxidants intake may offer protection against $\mathrm{Cd}$ induced health hazards.

\section{References:}

1. Aayad, F.; El-Safoury, S.; Zakaria, Y. and Emara, M. (1988): Occupational cadmium exposure in electroplating workers. Med. J. Cairo University. 56(3): $397-403$.

2. Aoshima, k.; Kawanishi, Y. and Fan, J. (1995): Cross-sectional assessment of renal function in the inhabitants of a cadmium-polluted area. Am. Clin. Lab Sci. 25: 439 - 503.

3. Armitage, P. (1971): Statistical Methods in Medical Research, Blackwell Scientific Publications, London.

4. Attia, DI.; Khaled, HN. and Nassar, Y. (2006): Effects of combined occupational exposure to solvents and cadmium on reproductive hormone concentrations in male workers. Egypt. J.Occup. Med. 30(1):147-62.

5. ATS: American Thoracic Society (1995): Standardization of spirometry. 1994 update. Am. J. Respir. Crit. Care Med. 152: 1107-36.

6. ATSDR (2003): Cercla priority list of hazardous substances. Available: www.atsdr.cdc. gov/97list.html.

7. Bajpai, R.; Wassem, M. and Kaw, J. (1994): Pulmonary response to cadmium and nickel coated fly ash. J.Environ.Pathol.Toxicol. 13(4): 251-57.

8. Bar-Sela, S.; Levy, M. and Westin, J. (1992): Medical findings in nickel-cadmium battery workers. J. Med. Sci. 28(8 - 9): 578 - 83.

9. Boudreau, J.; Vincent, R. and Nadeau, D. (1989): The response of pulmonary surfactant associated alkaline phosphatase following acute cadmium chloride inhalation. Am. Ind. Hyg. Assoc. J.50/7:331-35.
10. Chia. K., Tan, A. and Ong, C. (1992): Renal tubular dysfunction of cadmium- exposed workers. Ann. Acad. Med. Singapore. 21(6) : 756 -59 .

11. Danijela, D.C.; Milica, N.; Živorad, M.; Zorica P.B. and Vesna, M. (2006): Effect of supplemental magnesium on the kidney levels of cadmium, zinc, and copper of mice exposed to toxic levels of cadmium. Biol.tr.elem.res.114(13):281-291.

12. Edling, C.; Elinder, CE. and Randma, E. (1986): Lung function in workers using cadmium containing solders. Br.J.Ind.Med. 43(10): 657-62.

13. Edwin, V.; Eric, A. and Ganesh, S.(2008): Cadmium exposure is a known risk factor for prostate cancer and a new University of Rochester study suggests that zinc may offer protection against Cadmium. Science Daily .7:1-3.

14. El-Maraghy, SA.; Gad, MZ.; Fahim, AT. and Hamdy, MA. (2001): Effect of cadmium and aluminum Intake on the antioxidant status and lipid peroxidation in rat tissues. J.Bioch.Mol. Toxicol.15(4): 207-14.

15. Emara, A.M. and Abdel Samie, F. (1991): Cadmium. Egy.J.Occup.Med. 15(1): 65-74.

16. Ewis, A.; Refaat, T.; Kazuya, K. and Baba, Y. (2006): Understanding the hazardous effects of occupational and environmental cadmium exposure by monitoring the gene expression alteration in exposed lungs using a CDNA microarray. Egy.J.Occup.Med.30(2): 285-99.

17. Fahim, F.; Amr, M.; Emara, A. and Zayet, H. (1990): Changes in the level of Cadmium, Lead, Zinc and calcium in workers' sera in connection to occupational exposure and smoking habit. Egy.J.Occup.Med. 14(2): 189-202.

18. Fievez, L.; Kirschvink, N.; Zhang, W. and Lagente, V. (2009): Effects of betamethasone on inflammation and emphysema induced by Cadmium nebulisation in rats. Eur. J. Pharmacol. 606 (1-3): 210-14. 
19. Frankel, F.; Steeger, J. and Weinbaum, D. (1991): Induction of unilateral pulmonary fibrosis in the rat by cadmium chloride. Am.J.Respir. Cell Mol.Biol.5: 385-94.

20. Gaber, M. and Yassin, M. (1994): Environmental monitoring of $\mathrm{Cd}$ exposure in different Egyptian industries. Official document from the national institute of occupational safety and health. Egypt. pp.18-19.

21. Harrison, R. and Laxen, D. (1981): Lead pollution: Causes and Control. New York, Chapman and Hall.8.

22. Hendrick, D J. (2004): Smoking, cadmium and emphysema. Thorax 59:184-85.

23. IARC (1993): Meeting of the IARC working group on beryllium, cadmium, mercury and exposures in the glass manufacturing industry. Scand.J.Work Environ. Health 19 (5): 360-63.

24. Iwata, K.; Saito, H. and Nakano, A. (1991): Association between renal tubular dysfunction and mortality among residents in a cadmium polluted area. Tohoku J. Exp. Med. 164: 93 - 102.

25. Jakabowski, M.; Abramowska-Guzik, A.; Szymczak,W. and Trzcinka-Ochocka, M. (2004): Influence of long term occupational exposure to cadmium on lung function tests results. Int.J.Occup.Med.Environ.Health 17(3):361-8.

26. Jan-Dar, L.; Su-Mei, W.; Lieng-Yi, L. and Shaw-Yeu, J. (2009): Cadmium concentration and metalothionein expression in Prostate cancer and benign prostatic hyperplasia of Humans. J. Formosan Med.Ass. 108:554-59.

27. Järup L. (2002): Cadmium overload and toxicity. Nephrol. Dial. Transplant. 17:

28. Jarup, L. and Elinder, C. (1993) Incidence of renal stones among Cadmium exposed battery workers . Br. J. Ind. Med. 50(7):598-602.

29. Järup, L.; Persson, B.; Edling, C and Elinder, C.G. (1993): Renal function impairment in workers previously exposed to cadmium, Nephron 64: 75-81.
30. Kamiyema, T.; Miyakawa, H. and Sato, C. (1995): Effects of one year cadmium exposure on livers and kidneys and their relation to glutathione levels. Res. Commun. Med. Path. Pharmacol. 88(2): 177 - 86 .

31. Kawada, T.; Tohyama, C. and Suzuki, S. (1990): Significance of excretion of urinary indicator proteins for a low level of occupational exposure to cadmium. Int. Arch. Occup. Environ. Health. 62: $95-100$.

32. Kazantzis, G. (2004): Cadmium, osteoporosis and calcium metabolism. Biometals. 17(5):49398.

33. Kipling, MD. and Waterhouse, JA. (1967): Cadmium and prostatic cancer. Lancet 1: 73031.

34. Kischvink, N.; Martin, N. and Fievez, L. (2006): Airway inflammation in cadmium-exposed workers is associated with pulmonary oxidative stress and emphysema. Free Radic.Res.40(3): 241-50

35. Klaassen, C.; Liu, J. and Diwan, B. (2009): Metallothionein protection of cadmium toxicity. Toxicol. Appl. Pharmacol. 238(3):215-20.

36. Herak-Kramberger, CM and Sabolic, I. (2001): The integrity of renal cortical brush-border and basolateral membrane vesicles is damaged in vitro by nephrotoxic heavy metals. Toxicology 56:139-47.

37. Kusakabe, T.; Nakajima, K.; Suzuki, K.; Nakazato, K.; Takada, H.; Satoh, T.; Arakawa, K. and Nagamine, T. (2008): The changes of heavy metal distribution in testes induced by cadmium exposure. Biometals. 21(1):71-81.

38. Lemen, RA.; Lee, JS.; Wagoner, JK. and Blejer, HP.(1976): Cancer mortality among cadmium production workers. Ann. N. Y. Acad. Sci. 271: 273-77.

39. Liu, J.; Kershaw, W. and Klaassen, C. (1992): Cadmium-induced hepatic endothelial cell injury in inbred strains of mice. Toxicology.75:5162. 
40. Magnus, P. (1981): Role of cadmium in carcinogenesis with special reference to cancer of prostate. Environ. Health Pro. 40:107-20.

41. Manca, D.; Ricard, A. and Chevalier, G. (1991): Studies on lipid peroxidation in rat tissues following administration of low and moderate doses of cadmium chloride. Toxicology. 67: $303-23$.

42. Mason, H.; Davidson, A. and Wright, A. (1988): Relations between liver cadmium and renal function in cadmium alloy workers. Br.J.Ind. Med. 45: 793-802.

43. Mitsumori, K.; Shibutani, M.; Sato, S.; Onadera, H.; Nakagawa, J.; Hayashi, Y. and Ando, M. (1998): Relationship between the development of hepato-renal toxicity and cadmium accumulation in rats given minimum to large amounts of cadmium chloride in the long term: Preliminary study. Arch.Toxicol. 72: 545-52.

44. Novelli, EL.; Vierira, EP.; Rodrigues, NL.; Ribos, BO.(1998): Risk assessment of cadmium on hepatic and renal tissue in rats. Environ. Res.79A:102-5.

45. OSHA (1990): Occupational Safety and Health Administration. Cadmium as a toxic agent. Part П. Federal Register. 55: 4052.

46. Patrik, L. (2003): Toxic metals and antioxidants in arsenic and cadmium toxicity. Altern.Med. Rev. 8(2):106 - 28.

47. Perry, R. and Young, R. (1997): Handbook of air pollution analysis. Perry, R. and Young, R. eds. London: Chapman \& Hall. pp. 67.

48. Pocock, S.; Delves, H. and Clayton, B. (1988): Blood cadmium concentration in general population of British middle aged men. Hum. Toxicol. 7: 95-103.

49. Prasad, R. and Nath, R. (1995): Cadmium-induced nephrotoxicity in rhesus monkeys in relation to protein calorie malnutrition. Toxicology. 100: 89 - 100 .

50. Renugadevi, J. and Milton, P. (2009): Quercetin protects against oxidative stress - related renal dysfunction by cadmium. Toxicol. Path. 608:1-2.

51. Robert, A.; Jie, L.and Michael, P. (2004): Cadmium and cancer of prostate and testis. Biometals. 17:555- 58 .

52. Ruppel, G. (2003): Ventilation and Ventilatory control tests. In: Ruppel, G. Editor. Manual of pulmonary function testing. 7th edition. MosbyYear book Inc. pp.8-24.

53. Sakurai, H.; Omae, K.; Toyama, T.; Higashi, T. and Nakadate, T. (1982): Cross-sectional study of pulmonary function in cadmium alloy workers. Scand.J.Work Environ.Health. 8(1): 12230.

54. Sangster, B.; de Groot, G.; Lober, JG.; Derks, HJ.; Krajnc, EI. and Savelkoul, TJ. (1984): Urinary excretion of cadmium, protein, beta 2 microglobulin and glucose in individuals living in a cadmium polluted area. Hum.Toxicol. 3(1): 7-21.

55. Satarug, S. and Moore, M. (2004): Adverse health effects of chronic exposure to low level cadmium in food stuffs and cigarette smoke. Environ. Health Perspect. 112(10): 1099-103.

56. Sato, K.; Kusaka, Y. and Okada, K. (1995): Direct effect of cadmium on citrate uptake by isolated renal brush border membrane. 80(1-3):161-65.

57. Shaikh, ZA.; Tohyama, C. and Nolan, CV. (1987): Occupational exposure to cadmium: effect on metallothionein and other biological indices of exposure and renal function. Arch. Toxicol. 59(5): 360-4.

58. Simth, T.; Petty, T. and Redding, J. (1986): Pulmonary effects of chronic exposure to air borne cadmium. Rev. Resp. Dis. 114: 161-69.

59. Siu, ER.; Mruk, DD.; Porto, CS. and Cheng, CY.(2009) : Cadmium-induced testicular injury. Toxicol. Appl. Pharmacol. 239(3):240-49.

60. Smith, DS.; Humphrey, PA. and Catalona, WJ. (1997): The early detection of prostate 
carcinoma with prostate specific antigen: The Washington University experience. Cancer 80(9):1853-6.

61. Sorahan, T. and Esmen, NA. (2004): Lung cancer mortality in UK nickel-cadmium battery workers, 1947-2000. Occup. Environ. Med.61:108-16.

62. Sudo, J.; Hayashi, T.; Kimura, S.; Kakuno, K.; Terui, J.; Takashima, K. and Soyama, M. (1996): Mechanism of nephrotoxicity induced by repeated administration of cadmium chloride in rats. J. Toxicol. Environ. Health 48:333-48

63. Suru, S. (2008): Onion and garlic extracts lessen cadmium- induced nephrotoxicity. Biometals 21(6): 623-33.

64. Tanimoto, A.; Hamada, T.; Koide, O. (1993): Cell death and regeneration of renal proximal tubular cells in rats with subchronic cadmium intoxication. Toxicol. Pathol. 21:341-52.

65. Thompson, IM.; Pauler, DK. and Goodman, PJ. (2004): Prevalence of prostate cancer among men with a prostate-specific antigen level < or $=4.0 \mathrm{ng}$ per milliliter. New Engl.J.Med. 350(22):2239- 46 .

66. Waalkes, M.; Anver, M. and Diwan, B. (1999): Carcinogenic effects of cadmium in the nobel
(NBL/Cr) rat: Induction of pituitary, testicular, and injection site tumors and proliferative lesions of prostate. Toxicol. Sci. 52:154-61.

67. Willers, S.; Schutz, A. and Attewell, R. (1988): Relation between lead and cadmium in blood and involuntary smoking of children. Scand.J.Work Environ.Health 14: 385-89.

68. Yang, L.; Wu, K.; Chiu, W. and Wang, S. (2009): The cadmium-induced death of mesangial cells results in nephrotoxicity. Autophagy. 5(4) :571-72.

69. Yoshida, M.; Miyajima, K.; Shiraki, K.; Ando, J.; Kudoh, K.; Nakae, D.; Takahashi, M. and Maekawa, A. (1999): Hepatotoxicity and consequently increased cell proliferation are associated with flumequine hepatocarcinogenesis in mice. Cancer Lett. 141:99-107.

70. Zeng, X.; Jin, T. and Nordberg, G. (2003): Changes of serum sex hormone levels and MT m-RNA expression in rats exposed to cadmium. Toxicology. 186:109-18.

71. Zhao, Y.; Chen, L,; Gao, S.; Toselli, P.; Stone, P. and Li, W. (2009): The critical role of the cellular thiol homeostasis in cadmium perturbation of the lung extracellular matrix. Toxicology. (under publication). 